\title{
ZNACZENIE MARTWEJ NATURY W POEZJI I ESEISTYCE CZESŁAWA MIŁOSZA
}

\section{Ewa DRYGLAS-KOMOROWSKA (Toruń)}

W ostatniej dekadzie temat związków twórczości Miłosza z malarstwem pojawiał się w literaturze kilkakrotnie. Zainteresowanie badaczy tym wątkiem oscyluje wokół dwóch problemów. Z jednej strony podkreślają oni fascynację Miłosza określoną metodą artystyczną przedstawiania rzeczywistości. Krzysztof Zajas mówi w tym kontekście o zainteresowaniu poety malarstwem realistycznym ${ }^{1}$. Także Kris van Heuckelom wspomina o fascynacji Miłosza malarstwem figuratywno-realistycznym. Zaznacza przy tym, że malarstwo jest dla poety ważnym punktem odniesienia, ale nie w zakresie tematyki, lecz — metody artystycznej². Z kolei Adam Dziadek akcentuje wyraźne uprzywilejowanie w poezji i eseistycznej refleksji Miłosza „scen rodzajowych”, czy też — innymi słowy — „malarstwa obyczajów”. Dziadek, inaczej niż van Heuckelom, zwraca więc uwagę na fascynację Miłosza określonym tematem malarskim — tematem rodzajowym, który autor Nieobjętej Ziemi pojmuje w duchu Baudelaire'a ${ }^{4}$.

Warto podkreślić, że w twórczości Miłosza oba te nurty fascynacji — tematem „malarstwa obyczajów” i metodą realistycznego przedstawiania rzeczywistości ${ }^{5}$ przenikają i dookreślają się wzajemnie. Jednak nie sposób przy tym nie zauważyć, że

${ }^{1}$ K. Zajas, Malarstwo w poezji Czestawa Miłosza, [w:] Intersemiotyczność. Literatura wobec innych sztuk i odwrotnie. Studia, pod red. S. Balbusa, A. Hejmeja, J. Niedźwiedzia, Kraków 2004, s. 180.

${ }^{2}$ K. van Heuckelom, „Patrzeć w promien od ziemi odbity”. Wizualność w poezji Czestawa Miłosza, Warszawa 2004, s. 27.

${ }^{3}$ A. Dziadek, Obrazy i wiersze. Z zagadnień interferencji sztuk w polskiej poezji wspótczesnej, Katowice 2004, s. 150.

${ }^{4}$ Zob.: E. Dryglas-Komorowska, ,Malarstwo obyczajów” wedtug Miłosza, [w:] Spotkania w przestrzeni myśli i sztuki, pod red. J. Bielskiej-Krawczyk, K. Ćwiklińskiego, S. Kołos, Toruń 2012, s. 561-582.

${ }^{5}$ O Miłoszowym pojmowaniu realizmu w sztuce zob.: E. Dryglas-Komorowska, „Realizmy" Miłosza, Topos $2010 \mathrm{nr}$ 2-3, s. 49-59. 
„malarstwo obyczajów” - jako istotny wątek twórczości Miłosza — nie wyczerpuje repertuaru malarskich tematów, które mieszczą się w horyzoncie zainteresowań poety. Obok, specyficznie pojmowanego, tematu rodzajowego, w sposób szczególny fascynować będzie poetę martwa natura. Warto przyjrzeć się bliżej kilku najważniejszym wątkom, wokół których skupiona jest Miłoszowa refleksja o tym temacie malarskim, którego początków szukać należy już w starożytności greckiej i rzymskiej, lecz który pełną samodzielność zyskał w sztuce europejskiej dopiero w szesnastym stuleciu ${ }^{6}$.

\section{Szetejnie jak Chardin}

Skąd wzięło się upodobanie Miłosza do malarstwa martwych natur? Odpowiedź na to pytanie jest niezwykle złożona i najprościej byłoby — jak się wydaje — rozpocząć wszelkie wyjaśnienia od posłużenia się kluczem biograficznym, na który wskazuje sam poeta $\mathrm{w}$ rozmowie z Aleksandrem Fiutem ${ }^{7}$. Trzeba by powrócić wraz z Miłoszem do dworu w Szetejniach, którego czasy świetności po części sportretowane zostały w Dolinie Issy, po części — w poemacie Świat. A obraz upadku dworu — czy raczej obraz jego szczątków - sugestywnie przedstawiony został w wierszu z tomu Na brzegu rzeki, będącym częścią cyklu zatytułowanego wymownie Litwa, po pięćdziesięciu dwóch latach.

Wspomnienia o domu w Szetejniach - domu istniejącym już tylko w pamięci poety - które przywołane zostają w Autoportrecie przekornym, wypełnione są zapamiętanymi przedmiotami: książkami, szufladami, kołowrotkami, obrazami martwych natur na ścianach. Poeta mówi o apteczce, będącej najbardziej magicznym pokojem we dworze. To tam, na półkach, stały ,miedziane, cudownego złotego koloru vermeille rozmaite garnuszki”, ${ }^{, 8}$. To właśnie wydobyte z pamięci przedmioty, a zwłaszcza owe garnuszki koloru vermeille i miedziane rondle ${ }^{9}$, zlewają się w wyobraźni Miłosza z zapamiętanymi obrazami martwych natur. Albo inaczej: w martwych naturach Holendrów XVII w. i Chardina odnajdywać będzie Miłosz przedmioty z rodzinnego domu i ogólną atmosferę dworu w Szetejniach. Oto jeden z kluczy do Miłoszowej fascynacji tym tematem malarskim: Szetejnie są w pamięci poety niczym Holandia XVII w., utrwalona w martwych naturach. I jak Chardin.

Obrazy Holendrów XVII w., ale też Chardina w wieku XVIII i Cézanne'a w wieku XX, uzna Miłosz za najwyższe osiągnięcia sztuki martwych natur ${ }^{10}$. Do tego upodobania powracać będzie wielokrotnie i w różnych kontekstach.

W rozmowie z Renatą Gorczyńską powie Miłosz, że Chardin i wszystkie jego „rondle miedziane” - to pewien zestaw, który do niego apeluje, rodzaj głębokiego przywiązania emocjonalnego, którego nie sposób wytłumaczyć, tak samo, jak trudno byłoby poecie racjonalnie wyjaśnić swoje upodobanie do „sensualnego zestawu kolo-

${ }^{6}$ Zob.: H. Małachowicz, Martwe natury mistrzów niderlandzkich, Warszawa 1993, s. 3.

7 Zob.: Cz. Miłosz, Czesława Miłosza autoportret przekorny. Rozmowy przeprowadził A. Fiut, Kraków 1988, s. 162-163.

${ }^{8}$ Tamże, s. 163.

${ }^{9}$ Miłosz, odpowiadając na pytanie Aleksandra Fiuta, potwierdza, że w Szetejniach były miedziane rondle; zob.: Czestawa Mitosza autoportret przekorny, s. 163 . O miedzianych rondlach Miłosz wspomina też w jednej z rozmów z Renatą Gorczyńską — tam stają się one jak gdyby synekdochą malarstwa Chardina; zob.: R. Gorczyńska, Podróżny świata. Rozmowy z Czesławem Miłoszem. Komentarze, Warszawa 1984, s. 198.

${ }^{10}$ Zob.: Cz. Miłosz, Wypisy z ksiag użytecznych, Kraków 1994, s. 73. 
rów" malarstwa Blake'a ${ }^{11}$. (Choć pewnie w przypadku emocjonalnego przywiązania do „rondli miedzianych” Chardina klucz biograficzny dworu w Szetejniach mógłby okazać się — jak już wspomniałam - niezwykle pomocny.) W innej rozmowie Miłosz wyznaje: „Mnie zawsze fascynował Chardin”; nie wskazuje jednak momentu, w którym zaczęła się ta fascynacja i nie określa wyraźnie, czy mogła się narodzić jeszcze przed wojną (,Trudno powiedzieć, w jakim stopniu późniejsze zainteresowania rzutują na poprzednie. [...] Ja nie jestem pewien, czy kiedy pierwszy raz byłem za granicą, właśnie Chardin mnie fascynował"12).

Można przypuszczać, że młody poeta zetknął się z twórczością francuskiego malarza już podczas swoich przechadzek po Luwrze (pod przewodnictwem Józefa Pankiewicza) w roku akademickim 1934/1935. Z notatek Józefa Czapskiego ${ }^{13}$ - jednego z uczestników tych przechadzek - wiadomo, że patron kapistów zatrzymywał się w Luwrze przed martwymi naturami Chardina i opowiadał o nich swoim słuchaczom. Mówił m.in. o „poezji treści malarskiej” i „rozkoszy zestawień kolorystycznych” jako cechach łączących malarstwo Chardina i Watteau ${ }^{14}$. Wówczas to - jak można domniemywać - Miłosz zetknął się również po raz pierwszy z malarstwem Cézanne’a i Holendrów XVII w. (podczas „,zwartej przechadzki po Luwrze” Pankiewicz zatrzymywał się - jak zanotował Józef Czapski - m.in. przed obrazami takich malarzy, jak: Adriaen van Ostade, Aert van der Neer i Adriaen van der Velde) ${ }^{15}$.

Podczas swojej podróży do Włoch w roku 1937 poeta podziwiał m.in. freski Signorellego i malarstwo sieneńskie. $Z$ okresu podróży włoskiej wspomina Miłosz poza tym kilka nazwisk malarzy, których dzieła pozostawiły ślad w jego pamięci: Antonio Pollaiuolo, Pietro Perugino. Jednak wydaje się, że owe włoskie fascynacje malarstwem nie pozostawiły w późniejszej twórczości Miłosza wyraźnego śladu. Pewnie dlatego poeta, zapytywany przez Aleksandra Fiuta o upodobania malarskie, wymieni jednym tchem - tuż za nazwiskami wspomnianych włoskich malarzy — nazwisko Chardina ${ }^{16}$. To właśnie francuski malarz „rondli miedzianych"17 — obok Cézanne’a i malarzy holenderskich — będzie towarzyszył autorowi Nieobjętej Ziemi w jego artystycznych poszukiwaniach.

${ }^{11}$ R. Gorczyńska, Podróżny świata, s. 198.

${ }^{12}$ Cz. Miłosz, Czestawa Miłosza autoportret przekorny, s. 26.

${ }^{13}$ Znamienne, że Miłosz, zapisując w Roku myśliwego (notatka z 29 maja 1988 r.) swoje wrażenia z wystawy prac Józefa Czapskiego, którą obejrzał kilka dni wcześniej, przywołuje obraz, który szczególnie utkwił mu w pamięci; jest to „martwa natura ze szmatą w kolorach szarości i bieli”; zob.: Cz. Miłosz, Rok myśliwego, Kraków 1991, s. 291.

${ }^{14}$ J. Czapski, Józef Pankiewicz. Życie i dzieło. Wypowiedzi o sztuce, Lublin 1992, s. 133.

${ }^{15}$ Zob.: tamże, s. 141-152.

${ }^{16}$ Tamże, s. 27. Miłosz powie wręcz: „No, ale później [tzn. po „okresie włoskim”? — E. D.-K.] moje zainteresowania szły raczej w kierunku Chardina".

${ }^{17}$ Maria Rzepińska wymienia charakterystyczny dla późnego okresu twórczości Chardina repertuar przedmiotów pojawiający się w jego martwych naturach: ,,[...] motywy rzeczowe to miedziany kociołek, koszyczek poziomek, kilka brzoskwiń, kaseta i dzbanek z pędzlami wszystko jak najbardziej zwyczajne i bezpretensjonalne”; zob.: M. Rzepińska, Siedem wieków malarstwa europejskiego, Wrocław 1991, s. 319-320. Charles Sterling mówi zaś o śladach obecności człowieka na Chardinowskich przedmiotach: „Chardin wybiera przedmiot zużyty, wypolerowany od dotknięć. W tym niezmiennie poruszającym wspólistnieniu życia z materią, człowiek jest stale obecny"; zob.: Ch. Sterling, Martwa natura. Od starożytności po wiek XX, przeł. J. Pollakówna, W. Dłuski, Warszawa 1998, s. 118. 
Mogą o tym świadczyć pewne wypowiedzi Miłosza (część z nich została już przeze mnie przywołana), w których — expressis verbis — podkreśla on swoje zainteresowanie Chardinem. Warto w tym kontekście zwrócić uwagę chociażby na wzmiankę z Roku myśliwego o przeglądaniu albumów Chardina z martwymi naturami ${ }^{18}$, czy też na zdanie z Kontynentów - o „staroświeckim guście” poety, przywiązanego do Chardina i Holendrów. Ale przecież, aby zrozumieć interesujące nas fascynacje malarskie autora Hyтnu o perle, należy poszukać głębiej, zejść pod powierzchnię — lakonicznych często - autokomentarzy poety.

\section{Pomiędzy widzeniem a ruchem pędzla}

Jest jeszcze jeden ważny klucz, obok biografii poety, który pozwala rzucić światło na Miłoszowe zainteresowanie martwą naturą, a mianowicie: pisma Schopenhauera, a ściślej — jego poglądy estetyczne. „[...] Szukałem w nim (nie ja jeden) pochwały sztuki jako lekarstwo na okrucieństwo życia” — powie Miłosz o autorze dzieła Świat jako wola i wyobrażenie. Aw Abecadle stwierdzi: „Ale, myślę, najbardziej oddziałał [Schopenhauer] głosząc wyzwolenie przez sztukę"19".

Sztuka jest dla Schopenhauera jednym z dwóch źródeł ulgi w cierpieniu, jakiego doświadcza każdy człowiek — żyjąc. Tylko współczucie — które stoi u podstaw etyki Schopenhauerowskiej - i kontemplacja sztuki mogą bowiem uwolnić człowieka od pędu woli, będącego przyczyną nieustającego, bolesnego niezaspokojenia:

A przy tym kontemplacja daje nam nie tylko ulgę, ale i najwyższe poznanie: poza nią bowiem ujmujemy tylko zmienne, przepływające obrazy rzeczy, ona zaś zatrzymuje ten przepływ, chwyta w rzeczach to, co stałe, niezmienne $[\ldots]^{20}$.

Kontemplacja wyzwala i oczyszcza zarówno tego, który spotyka się twarzą w twarz z dziełem sztuki, jak i samego artystę, który staje się przez moment patrzącym okiem, wolnym od popędów woli.

Miłosz kilkakrotnie powracać będzie do pism Schopenhauera, by przywołać jego refleksję dotyczącą holenderskich martwych natur, które gdański filozof stawiał najwyżej spośród dzieł malarstwa ${ }^{21}$. Martwe natury malarzy holenderskich z XVII w. są bowiem - jak powie Miłosz za Schopenhauerem — obrazem ,spokojnego, uciszonego stanu umysłu, wolnego od podszeptów woli”, są trwałym znakiem kontemplacji zwyczajnych przedmiotów, owocem duchowego spokoju artystów ${ }^{22}$.

Szczególnie interesujące było dla Miłosza w tym Schopenhauerowskim ujęciu sztuki przekonanie o tym, że ,umysł, wydobywający się z więzów Woli, może zdobyć się na ogląd o b i e k t y w n y" "23. Według gdańskiego filozofa taki ogląd rzeczy stał się udziałem holenderskich malarzy martwych natur:

To właśnie widać u tych godnych podziwu holenderskich artystów, którzy zwracali swoją

\footnotetext{
${ }^{18}$ Cz. Miłosz, Rok myśliwego, s. 98.

${ }^{19}$ Tenże, Abecadto, Kraków 2001, s. 279.

${ }^{20}$ Zob.: W. Tatarkiewicz, Historia filozofii, t. 2: Filozofia nowożytna do roku 1830, Warszawa 2007, s. 251.

${ }^{21}$ Zob.: Cz. Miłosz, Wypisy z ksiag użytecznych, s. 12-13, s. 96, s. 173; tenże, Abecadło, s. 280; tenże, Rok myśliwego, s. 243.

${ }^{22}$ Zob.: tenże, Wypisy z ksiag użytecznych, s. 12-13.

${ }^{23}$ Tenże, Abecadto, s. 280.
} 
czysto obiektywną percepcję ku najmniej znaczącym przedmiotom i wznieśli trwały pomnik swemu obiektywizmowi i swemu duchowemu spokojowi w obrazach martwych natur, na które nie możemy patrzeć estetycznie, nie doznając wzruszenia. Gdyż mówią nam one o spokojnym, uciszonym stanie umysłu artysty, wolnym od podszeptów woli, tak że mógł kontemplować nieznaczące rzeczy tak obiektywnie, tak, inteligentnie ${ }^{24}$.

Miłosz, nawiązując do tej myśli, będzie próbował zrekonstruować znaczenie pojęcia „oglądu obiektywnego”. Otóż artysta, który potrafi patrzeć obiektywnie, na chwilę zapomina o sobie; znika i roztapia się wówczas wszystko, co jego dotyczy. Staje się samym okiem, które patrzy ${ }^{25}$. „Sztuka obiektywna” w rozumieniu Miłosza będzie więc sztuką zapatrzoną w świat widzialny, ,,ciągle na nowo ofiarowujący się i odsłaniający się oku"26.

Wybierając utwory do swoich Wypisów z ksiagg użytecznych, Miłosz szukał między innymi takich wierszy, w których utrwalił się ten spokojny, wyciszony stan umysłu, jaki Schopenhauer odnajdywał w holenderskich martwych naturach. To dlatego poeta włączył do swojej „księgi olśnień” ${ }^{27}$ tak wiele utworów poetów Dalekiego Wschodu. O wartości poezji kontemplacyjnej będzie Miłosz mówił również między innymi we wstępie do swojej antologii poezji haiku ${ }^{28}$. To właśnie poezja chińska i japońska, a w sposób szczególny haiku, będzie w refleksji Miłosza usytuowana blisko sztuki tworzenia martwej natury. Poeci Dalekiego Wschodu, poeci Zen, skupieni na postrzeganej rzeczy, przekraczający granicę utożsamienia patrzącego ,ja” z oglądanym przedmiotem, postępują tak, jak malarze martwej natury, którzy „utrwalają stan kontemplacji przedmiotu w czasie pomiędzy jego widzeniem a ruchem pędzla" ${ }^{29}$.

W refleksji estetycznej Miłosza oba wątki - kontemplacyjnej poezji chińskiej i japońskiej oraz holenderskiej martwej natury — zostają więc splecione, a dokonuje się to w duchu filozofii Schopenhauera, której ważnym źródłem była, jak wiadomo, myśl filozoficzna Dalekiego Wschodu ${ }^{30}$. Sam Miłosz podkreśla w Wypisach, że estetyka Schopenhauerowska jest

nieco podobna do ratowniczego posłania księcia Siddharthy, zwanego Buddą, który ofiarował ludziom wyzwolenie z cierpień przez wyjście poza infernalne koło pożądań i lęków. Bo artysta według Schopenhauera oddaje się czynności jak najjaskrawiej „,nieżyciowej" w tym sensie, że warunkiem piękna jest pozbycie się na chwilę tych popędów, którym i artysta podlega jako jeden z dążących i zmagających się śmiertelnych ${ }^{31}$.

Zdaniem Miłosza martwa natura holenderska spełnia postulat tych filozofów, dla których to dystans jest istotą piękna. Obrazy malarzy z Holandii są zatem doskonałą realizacją zarówno Schopenhauerowskiego ideału sztuki obiektywnej, jak też myśli estetycznej Simone Weil. W martwej naturze holenderskiej wyraźna jest granica oddzielająca chwilę zobaczenia przedmiotu od chwili jego utrwalenia. Na tej granicy — pomiędzy widzeniem a ruchem pędzla — trwa kontemplacja artysty, pozostawiona w obrazie ${ }^{32}$.

${ }^{24}$ Cyt. z pism Schopenhauera za: Cz. Miłosz, Wypisy z ksiag użytecznych, s. 13.

${ }^{25}$ Tamże.

${ }^{26}$ Tamże, s. 15.

${ }^{27}$ Określenie samego Miłosza; zob. tamże.

${ }^{28}$ Zob.: tenże, Wprowadzenie, [w:] tegoż, Haiku, Kraków 1992, s. 10.

${ }^{29}$ Tamże, s. 173.

${ }^{30}$ Zob.: W. Tyburski, A. Wachowiak, R. Wiśniewski, Historia filozofii i etyki do wspótczesności: źródta i komentarze, Toruń 2002, s. 435; W. Tatarkiewicz, Historia filozofii, s. 249.

${ }^{31}$ Cz. Miłosz, Wypisy z ksiag użytecznych, s. 12.

${ }^{32}$ Zob. tamże, s. 13, s. 173; tenże, Abecadło, s. 280. 


\section{Co się ostaje, ustanawiają artyści}

Twórca martwej natury, który kieruje swoją percepcję w stronę zwykłego przedmiotu, na chwile zapomina o sobie, aby móc kontemplować, to znaczy - patrzeć obiektywnie. W ten sposób może on - podobnie jak poeta Zen - wejrzeć w życie rzeczy, głosić jej istnienie. Ten sposób patrzenia będzie niezwykle bliski Miłoszowi.

W Osobnym zeszycie z tomu Hymn o perle poeta poprowadzi trzy osoby, między innymi malarza Mieczysława, na „,niemożliwe spotkanie” do pracowni Cézanne’a. Sam także będzie chciał spotkać się z malarzem z Aix ${ }^{33}$. W poetyckim monologu zapisze Miłosz wyznanie artystycznej wspólnoty obu artystów: poety i malarza, poszukujących „chwili zobaczenia uwolnionej od oczu”, innymi słowy - Schopenhauerowskiego spojrzenia obiektywnego, kontemplacyjnego.

„Późny uczeń” Cézanne'a, malarz Mieczysław, podobnie jak jego mistrz ${ }^{34}$, malował martwe natury: „Gliniany dzban i jabłko: / w to był wpatrzony i tym zapełniał płótna”. On też „prawie już dosięgał”. Bowiem zadaniem artysty jest, według Miłosza, ściganie wymykającej się Rzeczywistości — widzialnego świata, czyli zatrzymywanie rzeczy, na moment, w pełni ich „bycia”. I wbrew prawu przemijalności, które sprawia, że cokolwiek jest upragnione - zmienia się natychmiast, jak ,pień prowansalskiej sosny kiedy przychylić głowę". Jak pień tej sosny, którą ze swymi sztalugami, dzień po dniu, okrążał Cézanne.

Ci artyści, którzy ścigają wymykającą się Rzeczywistość, wierni są kategorii mimesis w sztuce i realistycznemu oglądowi świata. To znaczy: wierzą w realność siebie i tego, co przedstawiają. I wydaje się, że według Miłosza malarze Holandii zajmują wśród takich artystów miejsce szczególne. Ich obrazy mają w sobie „mięsistość”, która jest znakiem gęstości i bujności świata, a której wyrzekły się „różne eteryczne awangardy"35. Dlatego to holenderskie martwe natury - obok homeryckich rapsodów nazwie Miłosz w Ogrodzie nauk ,,aktami zażegnującymi”, aktami wymierzonymi przeciwko „naciskowi nicości” ${ }^{36}$. Dzięki nim spełniają się słowa Hölderlina: „Co się ostaje, ustanawiają poeci”, czy też szerzej: artyści.

Znamienny w tym kontekście jest także Miłoszowy wiersz Realizm z tomu $\mathrm{Na}$ brzegu rzeki, w którym poeta opowiada się po stronie malarstwa holenderskiego, zażegnującego niewiarę człowieka w substancjalność świata i człowieka ${ }^{37}$. Tę niewiarę, która wsącza się w umysły od „stu, dwustu lat”. Miłosz maluje w swoim wierszu obraz martwej natury, który nie jest opisem żadnego konkretnego obrazu; nie jest więc ekfrazą sensu stricto, lecz raczej — hypotypozą holenderskiej martwej natury:

A jednak to tutaj, chleb, talerz cynowy,

Półobrana cytryna, orzechy i chleb

Trwają i to tak mocno, że trudno nie wierzyćc ${ }^{38}$.

${ }^{33}$ Tenże, Osobny zeszyt. Przez galerie luster, [w:] tegoż, Hymn o perle, Kraków 1983, s. $61-63$.

34 „Cézanne malował martwe natury przez całe życie i odbijają się w nich wszystkie jego poszukiwania"; zob.: Ch. Sterling, Martwa natura, s. 135.

${ }^{35}$ Por.: Cz. Miłosz, Kontynenty, Kraków 1999, s. 9.

${ }^{36}$ Tenże, O twórcach, [w:] tegoż, Ogród nauk, Kraków 1998, s. 128-129.

${ }^{37}$ Zob.: tenże, Realizm, [w:] tegoż, Na brzegu rzeki, Kraków 1994, s. 25-26.

${ }^{38}$ Tamże, s. 25. 
Na marginesie dodać trzeba, że hypotypozę traktuję tu zgodnie z ustaleniami Adama Dziadka jako figurę, która „zdaje się sugerować analogię z jakimś obrazem lub z jakimś charakterystycznym typem obrazowania malarskiego"39. Oznacza to, że opis w hypotypozie nie odnosi się do konkretnego dzieła sztuki — jak to ma miejsce w ekfrazie - lecz raczej w sposób pośredni przywołuje pewien obraz lub całą klasę dzieł malarskich o podobnej tematyce ${ }^{40}$. W przytoczonym przeze mnie fragmencie utworu Realizm poeta odsyła czytelników do klasy obrazów, którą można - co oczywiste zamknąć w formule „martwej natury holenderskiej”. Tak samo rzecz ma się zresztą z pozostałymi obrazami stworzonymi w wierszu przez poetę: „tamte krajobrazy”, „,niebo chmurne, skąd wystrzela promień / I w środku ciemnych równin jarzy się plama blasku”, ,brzeg zatoki, gdzie chaty, czółna, / I na żółtawym lodzie maleńkie postacie” — to nic innego, jak hypotypoza realistycznego holenderskiego pejzażu.

\section{Nakryty stół}

Martwa natura holenderska jest aktem zażegnującym, skierowanym przeciwko nicości. Ten temat malarski — zapośredniczony przez obejrzane dzieła mistrzów holenderskich, ale też francuskich: Chardina i Cézanne'a — stanie się również ważnym elementem wyobraźni poety.

Szczególnie często sięga Miłosz w swoich utworach zwłaszcza po jeden typ martwej natury - przedstawienie zastawionego stołu. Zresztą, gdy poeta w Wypisach wspomina o procesie usamodzielniania się tematu martwej natury w sztuce, wymienia jeden konkretny typ tego rodzaju przedstawień: „talerze, mięsiwa, owoce, czyli to, co ludziom towarzyszy na ich stołach" ${ }^{41}$. Wskazuje więc bezpośrednio na jedną formę interesującego nas tematu malarskiego: Nakryty stół.

Ten rodzaj martwej natury znany jest w malarstwie już od starożytności; rozmaite wiktuały malowano wówczas albo pod postacią tzw. xenionu (,daru gościnności”) albo nakrytego stołu, który rozpowszechnił się na mozaikach epoki rzymskiej ${ }^{42}$. Jednak koncepcja „Nakrytego stołu” (czy też inaczej: „Posiłków”) w tej postaci, w jakiej znamy ją z obrazów Holendrów, wykształciła się około 1620 r. Wybitny znawca tego tematu malarskiego, Charles Sterling, w następujący sposób wyjaśnia tajemnicę piękna „Nakrytych stołów” Willema Claesza Hedy — holenderskiego mistrza martwych natur:

Heda potrafił wokół swych przedmiotów zasugerować nieskończoną przestrzeń, pośród której nabierają one spokojnego ciężaru. Wyodrębnione w ten sposób z przejrzystego niebytu, przedstawiają niezachwianą trwałość materii przynoszącą spokój duchowy ${ }^{43}$.

Trudno byłoby odnieść poetyckie obrazy Miłoszowych martwych natur do konkretnych dzieł malarskich: Holendrów, Chardina, Cézanne'a. Zresztą brak w wierszach autora Dalszych okolic wskazówek metajęzykowych umożliwiających taką referencję.

\footnotetext{
${ }^{39}$ Zob.: A. Dziadek, Obrazy i wiersze, s. 76-83. Dziadek wskazuje na fragment wiersza Jadalnia Miłosza (z cyklu Świat. Poema naiwne) jako na dobry przykład hypotypozy: „Na ścianie obraz. Przedstawiona zima: / Między drzewami ślizga się na lodzie / Gromada ludzi, dym idzie z komina / I wrony lecą w pochmurnej pogodzie".

${ }^{40}$ Zob. tamże, s. 82.

${ }^{41}$ Cz. Miłosz, Wypisy z ksiag użytecznych, s. 73.

${ }^{42}$ Ch. Sterling, Martwa natura, s. 22-23.

${ }^{43}$ Tamże, s. 72.
} 
Jednak nie ulega wątpliwości, że to właśnie martwe natury, a zwłaszcza „Nakryte stoły”, są ważnym elementem poetyckiej wyobraźni Miłosza.

Czasem są to poetyckie obrazy inspirowane malarstwem, jak w cytowanym wierszu Realizm. Niekiedy Miłoszowe martwe natury są wspomnieniami widzianych niegdyś „Nakrytych stołów”, na które poeta spogląda z dystansu. Tak jest chociażby w wierszu W Szetejniach z tomu Na brzegu rzeki, gdzie znaleźć można martwą naturę, będącą świadectwem dzieciństwa i rodzinnej okolicy: „Na stole wędliny, plastry miodu w glinianej misie" ${ }^{, 4}$.

Wreszcie pojawiają się też w Miłoszowych utworach martwe natury, którym poeta nadaje znaczenie symboliczne. Ich przegląd zacząć trzeba od wspomnianej już martwej natury holenderskiej z utworu Realizm, złożonej z chleba, talerza cynowego, półobranej cytryny i orzechów, która w wierszu staje się — jak już zostało powiedziane potwierdzeniem realności i substancjalności świata. I wydaje się, że podobną funkcję spełnia martwa natura w wierszu $W$ potudnie $\mathrm{z}$ tomu Nieobjęta ziemia ${ }^{45}$. Poeta wspomina w nim, jak wraz z dwiema kobietami siedział ,w górskiej oberży, wysoko, nad burzliwą zielenią kasztanów”, pośród zapachu „korsykańskiego lata”. I nagle minione życie splata się z teraźniejszością, a przeszłość staje się namacalna, dotykalna — staje się tu i teraz — i zamienia w czas teraźniejszy:

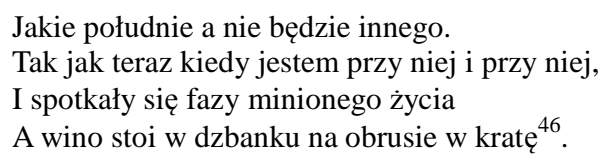

Jakie południe a nie będzie innego.

Tak jak teraz kiedy jestem przy niej i przy niej, I spotkały się fazy minionego życia

A wino stoi w dzbanku na obrusie w kratę ${ }^{46}$.

„Są wiersze, które próbują uchwycić jedną chwilę, niejako obrysować ją i utrwalić, czyli zatrzymać film czasu, żeby przyglądnąc się jednej z jego klatek" — powie Miłosz $\mathrm{w}$ innym miejscu ${ }^{47}$. I wydaje się, że takim wierszem jest $W$ południe. Moment wieczny uobecnia się w tym utworze dzięki zapamiętanemu szczegółowi - martwej naturze: „A wino stoi w dzbanku na obrusie w kratę”. „Nakryty stół” w wierszu Miłosza zostaje wyrwany ze strumienia przemijających rzeczy. To życie, które poeta sławi, życie objawiające się w byciu przedmiotów i ludzi, najpełniej opisać można za pomocą bezsłownego wołania: „Ooo śpiewało we mnie, ooo”.

„Nakryty stół” w wierszach Miłosza jest domeną bytu. Jego krawędzie wyznaczają tę cienką granicę, która oddziela życie od śmierci, istnienie od niebytu, ład od bezładu. Tuż obok „mleka w dzbanku” pełznie bowiem, jak wyznaje poeta w jednym ze swych utworów, „nieprzebłagana, stalowoszara nicość”,48.

Tak będzie również w wierszu Stót II z Nieobjętej ziemi ${ }^{49}$. Ludzie zgromadzeni przy stole, „w tej oberży nad chwiejną wspaniałością morza” są śmiertelni i znikają. Stół staje się tu symbolem życia, które jest wspólnym patrzeniem, dotykaniem i smakowaniem. Poeta wie, że poza krawędzią stołu rozciąga się wspólnota śmiertelnych. Ale jednocześnie szuka trwałości — i odnajduje ją w przedmiotach na stole, w martwej naturze:

I tylko sprawdzam, co tutaj jest trwałe:

Noże z rogowym trzonkiem i cynowe misy,

\footnotetext{
${ }^{44}$ Cz. Miłosz, W Szetejniach, [w:] tegoż, Na brzegu rzeki, s. 76.

${ }^{45}$ Tenże, W potudnie, [w:] tegoż, Nieobjęta Ziemia, Kraków 1988, s. 56.

${ }^{46}$ Tamże.

${ }^{47}$ Tenże, Wypisy z ksiag użytecznych, s. 173.

${ }^{48}$ Tenże, Na plaży, [w:] tegoż, Dalsze okolice, Kraków 1991, s. 53.

${ }^{49}$ Tenże, Stót II, [w:] tegoż, Nieobjęta Ziemia, s. 130.
} 
Niebieska porcelana, mocna, chociaż krucha,

I, jak skała warowna pośrodku odmętu,

Wygładzony na połysk, stół z ciężkiego drzewa ${ }^{50}$.

Podobne symboliczne znaczenie przypisać można martwej naturze $\mathrm{z}$ wiersza Mistrz mego rzemiosła z tomu Druga przestrzeñ ${ }^{51}$. Stół, na nim szklanka i dwa jabłka, zostają ustawione tu ,na samym brzegu otchłani” i wyznaczają granicę między życiem a nicością. Są dowodem na to, że ,przemijanie ludzi i rzeczy nie jest jedyną tajemnicą czasu”. Są uświetnieniem „niedosiężnego Teraz”. Oznacza to, że utrwalone w martwej naturze przedmioty zostają zatrzymane „między widzeniem a ruchem pędzla”. Artysta kontemplujący „bycie” rzeczy daje im wieczne trwanie, nieustający czas teraźniejszy. Daje im ,Teraz” — niedosiężne człowiekowi.

\section{THE IMPORTANCE OF STILL LIFE IN CZESEAW MILOSZ'S POETRY AND ESSAY WRITING}

The article provides a glance perspective on Miłosz's poetry and essay writing through an issue of a relation with fine arts. The Author takes up a problem of both the method (realism; thesis of world's reality-against nothingness) and the subject (generic scenes); she turns towards Miłosz's interest in Chardin, Dutch still lives, Cézanne and passion for haiku, introducing a meditative motif. First of all, what is worthy of emphasizing here is the hypotyposis consideration (e.g. type of painting imagining) remaining in conflict with ecphrasis (work description itself).

KEY WORDS: Cz. Miłosz; poetry; essay; still life; art correspondence.

\footnotetext{
${ }^{50}$ Tamże.

${ }^{51}$ Tenże, Mistrz mego rzemiosta, [w:] tegoż, Druga przestrzeń, Kraków 2006, s. 15-16.
} 